\title{
Long-term survival after liver transplantation in children with metabolic disorders
}

Kayler LK, Merion RM, Lee S, Sung RS, Punch JD, Rudich SM, Turcotte JG, Campbell DA Jr, Holmes R, Magee JC. Long-term survival after liver transplantation in children with metabolic disorders Pediatr Transplantation 2002: 6: 295-300. (C) 2002 Blackwell Munksgaard

Abstract: Background: Liver transplantation for inherited metabolic disorders aims to save the patient's life when the disorder is expected to progress to organ failure, and to cure the underlying metabolic defect. Methods: We retrospectively analyzed 146 pediatric liver transplants (28 metabolic; 118 non-metabolic) performed between 1986 and 2000. Results: Twenty-eight transplants were performed in 24 children with metabolic disease ( 8 females; 16 males; age range 3 months to $17 \mathrm{yr}$ ). Indications included $\alpha-1$-antitrypsin deficiency $(\mathrm{n}=8)$, two cases each of hyperoxaluria type 1, Wilson's disease, hereditary tyrosinemia type I, citrullinemia, methylmalonic acidemia, and one case each of propionic acidemia, CriglerNajjar syndrome type I, neonatal hemachromatosis, hemophilia B, Niemann-Pick disease type B, and cysticfibrosis. Eighteen transplants were whole organ grafts and 10 were lobar or segmental. Auxiliary liver transplants were performed in two patients and three received combined liver-kidney transplants. There were three deaths from sepsis, two from chronic rejection, and one from fulminant hepatitis. Seven of 10 patients currently of school age are within $1 \mathrm{yr}$ of expected grade and three who had pretransplant developmental delay have remained in special education. Actuarial survival rates at 5 and $10 \mathrm{yr}$ are $78 \%$ and $68 \%$, respectively, with mean follow-up in excess of $5 \mathrm{yr}$. These results compare favorably to 100 pediatric patients transplanted for non-metabolic etiologies $(65 \%$ and $61 \%$, respectively) $(\mathrm{p}=\mathrm{NS})$. Conclusions: Pediatric liver transplantation for metabolic disorders results in excellent clinical and biochemical outcome with long survival and excellent quality of life for most recipients.

\author{
Liise K. Kayler', Robert M. Merion', \\ Samuel Lee ${ }^{1,2}$, Randall S. Sung ${ }^{1,3}$, \\ Jeffrey D. Punch ${ }^{1}$, Steven M. \\ Rudich ${ }^{1}$, Jeremiah G. Turcotte ${ }^{1}$, \\ Darrell A. Campbell Jr ${ }^{1}$, Ronald \\ Holmes $^{4}$ and John C. Magee ${ }^{1}$ \\ Departments of ${ }^{1}$ Surgery and ${ }^{4}$ Pediatrics, University \\ of Michigan Health System, Ann Arbor, Michigan, \\ USA, ${ }^{2}$ Department of Surgery, Hallym University, \\ Seoul, Korea, ${ }^{3}$ Department of Surgery, Recanati- \\ Miller Transplantation Institute, Mount Sinai \\ School of Medicine, New York, USA
}

Key words: liver transplantation - metabolic disorders - pediatric transplantation - metabolic disease

John C. Magee, MD, Department of Surgery, University of Michigan Health System, 2926

Taubman Center, PO Box 0331, 1500 East Medical Center Drive, Ann Arbor, MI 48109-0331, USA Tel.: 734-936-9623

Fax: 734-763-3187

E-mail: mageej@umich.edu

Accepted for publication 29 January 2002

\section{Introduction}

In most pediatric transplant centers, metabolic liver disease is the second most common indication for liver transplantation after biliary atresia (1-4). Liver transplantation in inherited metabolic disorders has a twofold aim: to save the patient's life when the disorder is expected to progress to hepatic (or other organ) failure and to

Abbreviations: EBV: Epstein-Barr viral syndrome, CNS: CriglerNajjar syndrome, B-UGT: bilirubin-UDP-glucuronosyltransferase. cure the underlying metabolic defect. Unlike patients with biliary atresia who develop symptoms related to chronic liver disease, many patients with metabolic liver diseases are transplanted to prevent potential complications. The clinical status of these patients at the time of transplant is usually better than for other chronic hepatobiliary diseases, and the survival rate of patients is higher $(3,4)$. In this report, we compare the outcome of pediatric patients transplanted for metabolic disease to children transplanted for non-metabolic etiologies. Additionally, we assessed outcomes in children 
with metabolic disease stratified by the presence or absence of underlying parenchymal liver damage.

\section{Patients and methods}

Between 1986 and 2000, 124 pediatric patients at the University of Michigan Health System received 146 liver transplants. Of these, 28 transplants were performed in 24 children with liver-associated metabolic disease ( 8 females; 16 males; mean age $9 \pm 6$ yr, range 3 months to $17 \mathrm{yr}$ ). Indications included $\alpha-1$-antitrypsin deficiency $(n=8)$, primary hyperoxaluria type $1(n=2)$, Wilson's disease $(n=2)$, hereditary tyrosinemia type I $(n=2)$, citrullinemia $(n=2)$, methylmalonic acidemia $(n=2)$, propionic acidemia $(n=1)$ Crigler-Najjar syndrome type I $(n=1)$, neonatal hemochromatosis $(n=1)$, hemophilia B $(n=1)$, Niemann-Pick disease type $B(n=1)$, and cystic fibrosis $(n=1)$ (Tables 1 and 2). Eighteen transplants were whole organ grafts and 10 were lobar or segmental grafts. Auxiliary liver transplants were performed in two patients (Crigler-Najjar; methylmalonic acidemia) and three received combined liverkidney transplants (hyperoxaluria $[\mathrm{n}=2]$; methylmalonic acidemia $[\mathrm{n}=1]$ ). Retransplants were performed in four cases (two each of chronic rejection and hepatic artery thrombosis). Initial immunosuppression was based on cyclosporin A $(\mathrm{n}=20)$ or tacrolimus $(n=4)$, in combination with steroids and azathioprine $(n=17)$, mycophenolate mofetil $(\mathrm{n}=4)$, basiliximab (Simulect, Novartis, Basel, Switzerland) $(\mathrm{n}=1)$ or anti-CD3 monoclonal antibody (Orthoclone-OKT3; Ortho Pharmaceuticals, Raritan, NJ) ( $\mathrm{n}=1)$.

Analysis of patient survival was performed by Kaplan-Meier life-table analysis. Statistical analyses were performed using StatView version 4.5 (Abacus Concepts Inc., Berkeley, CA). Statistical significance was accepted at $\mathrm{p}<0.05$.

\section{Results}

In the group with metabolic disease, actuarial patient survival rates at 5 and $10 \mathrm{yr}$ were $78 \%$ and $68 \%$, respectively, with mean follow-up greater than $5 \mathrm{yr}$. These results compared favorably to
100 pediatric patients transplanted for nonmetabolic etiologies $(65 \%$ and $61 \%$, respectively; $\mathrm{p}=$ NS vs. metabolic group) (Fig. 1). A subset analysis of patients with metabolic disease and cirrhosis (Table 1) and those with metabolic disease and normal liver function (Table 2), demonstrated comparable actuarial survival rates at $5 \mathrm{yr}(79 \%$ and $75 \%$, respectively).

Among the 24 children in the metabolic group, 12 were treated for graft rejections by steroid bolus alone $(n=4)$ or in combination with OKT3 $(n=8)$. Three patients developed Epstein-Barr viral syndrome (EBV) and potential post-transplant lymphoproliferative disease. The etiology of metabolic disease in these patients was tyrosinemia, methylmalonic acidemia and Crigler-Najjar. Only one patient had been treated for rejection with steroid pulses and OKT3 prior to the onset of elevated EBV titers; all were successfully treated with a reduction of immunosuppression and intravenous ganciclovir. There were three deaths from sepsis, two from chronic rejection, and one due to fulminant hepatitis (Tables 1 and 2). Seven of 10 patients currently of school age are within $1 \mathrm{yr}$ of expected grade and three who had pretransplant developmental delay have remained in special education.

\section{Discussion}

For the majority of children with metabolic disease, the decision to offer liver transplantation is made easily, since the extent of liver damage usually provides a conventional indication. Additional benefits of liver transplantation

Table 1. Metabolic disorders with structural liver disease

\begin{tabular}{|c|c|c|c|c|c|c|c|}
\hline $\begin{array}{l}\text { Patient } \\
\text { number }\end{array}$ & Diagnosis & Gender & $\begin{array}{l}\text { Age at } \\
\text { diagnosis }\end{array}$ & $\begin{array}{l}\text { Age at } \\
\text { transplant }\end{array}$ & $\begin{array}{c}\text { Graft type } \\
\text { (retransplant graft type) }\end{array}$ & $\begin{array}{l}\text { Follow-up } \\
\text { (months) }\end{array}$ & Death \\
\hline 1 & $\alpha$-1-antitrypsin deficiency & $M$ & neonate & $9 \mathrm{yr}$ & $\begin{array}{c}\text { Whole liver } \\
\text { (Left lobe; Left lobe) }\end{array}$ & 54 & Y \\
\hline 2 & $\alpha-1$-antitrypsin deficiency & $\mathrm{F}$ & neonate & $4 \mathrm{yr}$ & Segments II, III, IV & 73 & $\mathrm{~N}$ \\
\hline 3 & $\alpha-1$-antitrypsin deficiency & $M$ & neonate & $4 \mathrm{yr}$ & Segments II, III, IV & 86 & $\mathrm{~N}$ \\
\hline 4 & $\alpha-1$-antitrypsin deficiency & $\mathrm{F}$ & $6 \mathrm{yr}$ & $13 \mathrm{yr}$ & Whole liver & 91 & $\mathrm{~N}$ \\
\hline 5 & $\alpha-1$-antitrypsin deficiency & $M$ & neonate & $4 \mathrm{yr}$ & Whole liver & 66 & $\mathrm{~N}$ \\
\hline 6 & $\alpha-1$-antitrypsin deficiency & M & $12 \mathrm{yr}$ & $13 \mathrm{yr}$ & Whole liver & 24 & Y \\
\hline 7 & $\alpha-1$-antitrypsin deficiency & M & $15 \mathrm{yr}$ & $17 \mathrm{yr}$ & Whole liver & 51 & $\mathrm{~N}$ \\
\hline 8 & $\alpha-1$-antitrypsin deficiency & $\mathrm{F}$ & 4 months & $9 \mathrm{yr}$ & Whole liver & 19 & $\mathrm{~N}$ \\
\hline 9 & Wilson's Disease & $\mathrm{F}$ & $17 \mathrm{yr}$ & $17 \mathrm{yr}$ & Whole liver & 18 & $\mathrm{~N}$ \\
\hline 10 & Wilson's Disease & $\mathrm{F}$ & neonate & $17 \mathrm{yr}$ & Whole liver & 24 & $\mathrm{~N}$ \\
\hline 11 & Tyrosinemia & $\mathrm{F}$ & neonate & $13 \mathrm{yr}$ & Whole liver & 23 & $\mathrm{~N}$ \\
\hline 12 & Tyrosinemia & M & neonate & $3 \mathrm{yr}$ & Whole liver & 18 & $\mathrm{~N}$ \\
\hline 13 & Neonatal hemochromatosis & M & neonate & 3 months & $\begin{array}{l}\text { Segments II, III, IV } \\
\text { (Left lobe) }\end{array}$ & 15 & Y \\
\hline 14 & Hemophilia B & M & 21 months & $14 \mathrm{yr}$ & Whole liver & 30 & Y \\
\hline 15 & Niemann-Pick Type B & M & $12 \mathrm{yr}$ & $12 \mathrm{yr}$ & Whole liver & 113 & $\mathrm{~N}$ \\
\hline 16 & Cystic fibrosis & M & 12 months & $4 \mathrm{yr}$ & Whole liver & 16 & $\mathrm{~N}$ \\
\hline
\end{tabular}




\section{Long-term survival after liver transplantation}

Table 2 Patients with metabolic disease without structural liver damage

\begin{tabular}{|c|c|c|c|c|c|c|c|}
\hline $\begin{array}{l}\text { Patient } \\
\text { number }\end{array}$ & $\begin{array}{c}\text { Diagnosis } \\
\text { (phenotype) }\end{array}$ & Gender & $\begin{array}{l}\text { Age at } \\
\text { diagnosis }\end{array}$ & $\begin{array}{l}\text { Age at } \\
\text { transplant }\end{array}$ & $\begin{array}{c}\text { Graft type } \\
\text { (re-transplant graft type) }\end{array}$ & $\begin{array}{l}\text { Follow-up } \\
\text { (months) }\end{array}$ & Death \\
\hline 17 & Primary hyperoxaluria & M & 5 months & $1 \mathrm{yr}$ & $\begin{array}{c}\text { Whole liver } \\
\text { Kidney transplant }\end{array}$ & 66 & $\mathrm{~N}$ \\
\hline 18 & Primary hyperoxaluria & M & $7 \mathrm{yr}$ & $8 \mathrm{yr}$ & $\begin{array}{l}\text { Segments II, III, IV } \\
\text { Kidney transplant }\end{array}$ & 7 & Y \\
\hline 19 & Citrullinemia & $\mathrm{F}$ & neonatal & $11 \mathrm{yr}$ & Segments II, III, IV & 60 & $\mathrm{~N}$ \\
\hline 20 & Citrullinemia & M & prenatal & $11 \mathrm{yr}$ & Whole liver & 52 & $\mathrm{~N}$ \\
\hline 21 & $\begin{array}{l}\text { Methylmalonic acidemia } \\
\text { (Methylmalonic CoA } \\
\text { mutase deficiency) }\end{array}$ & M & neonatal & $16 \mathrm{yr}$ & Whole liver & 13 & N \\
\hline 22 & $\begin{array}{l}\text { Methylmalonic acidemia } \\
\text { (mutase } 0 \text { deficiency) }\end{array}$ & $\mathrm{F}$ & neonatal & $13 \mathrm{yr}$ & $\begin{array}{l}\text { Heterotopic whole liver } \\
\text { Kidney transplant } \\
\text { (Heterotopic whole liver) }\end{array}$ & 47 & N \\
\hline 23 & Propionic Acidemia & M & neonatal & $3 \mathrm{yr}$ & Segments II, III & 3 & Y \\
\hline 24 & Crigler-Najjar Type I & M & 7 months & 10 months & Auxiliary segments II, III & 78 & $\mathrm{~N}$ \\
\hline
\end{tabular}

depend on the type of genetic defect, whether the enzymatic defect is located exclusively in the liver or diffusely throughout all tissues, and the extent and recoverability of extra-hepatic end-organ damage.

For example, in both $\alpha$-1-antitrypsin deficiency and Wilson's disease, the liver is the main source of enzymatic activity and transplantation provides complete reversal of the metabolic defect. Additionally, in Wilson's disease, where copper overload leads to a progressive accumulation of copper first in the liver and later in other tissues (especially the central nervous system), liver transplantation ameliorates neurological manifestations in most patients (5). Similarly, liver transplantation provides a metabolic cure in hemophilia $\mathrm{A}$ and $\mathrm{B}$ by providing the missing coagulation protein. However, due to the risks of operation and immunosuppression, liver transplantation should only be performed if hemophilia is complicated by cirrhosis from transfusionassociated hepatitis (6). In hereditary tyrosinemia type I, liver and other organ damage occur due to a widespread enzymatic defect leading to ineffective tyrosine metabolism. Toxic metabolic by-

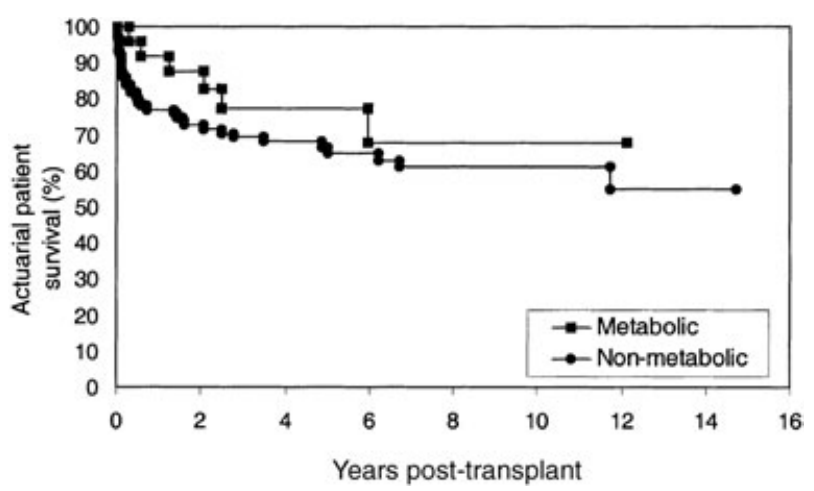

Fig. 1. Actuarial patient survival after liver transplantation. products accumulate and cause severe liver injury ranging from fulminant hepatitis to cirrhosis and hepatocellular carcinoma (7). The kidney and central nervous system are also affected. Liver transplantation treats the liver failure, precludes the development of hepatocellular carcinoma, prevents the recurrence of neurological crises, and may ameliorate renal impairment (8-10). In neonatal hemochromatosis, patients present with fulminant hepatic failure in infancy that usually progresses to death. Liver transplantation offers the opportunity to replace a metabolically defective organ and avoid otherwise fatal outcomes. However, since the etiology of this disorder may be multifactorial (11), surgical cure may only be partial.

In a separate group of patients with metabolic disease, the liver remains structurally normal while metabolic disease damages other tissues. The determination as to whether liver transplantation is indicated is more complex, and is dependent on the extent of organ involvement outside the liver and whether liver replacement alone will be sufficient to either prevent further deterioration or improve dysfunction in extrahepatic organs. Illustrative diseases include primary hyperoxaluria type I, urea cycle disorders, Crigler-Najjar syndrome, and disorders of organic acid metabolism.

Primary hyperoxaluria type I is characterized by the continuous excessive synthesis and excretion of oxalic acid, based on a deficiency of alanine glyoxylate aminotransferase. When the disease is pyridoxine-resistant, oxalosis results in progressive nephrocalcinosis, renal failure, and extrarenal oxalate deposits. The removal of the enzyme-deficient liver and its replacement with a normal one cures the liver-associated genetic defect and prevents the development of renal 
disease if performed early enough in the patient's course $(3,12,13)$. Unfortunately, many patients develop end-stage renal disease by the time the diagnosis is made. Combined liver and kidney transplantation is necessary in these patients. Isolated kidney transplantation fails to cure the metabolic defect and is usually associated with recurrent oxalate deposition, which often leads to graft failure (14). Auxiliary liver transplantation is not recommended, since the enzymatic defect in the native liver is associated with ongoing excess oxalate production (15).

In urea cycle disorders, the biosynthesis of urea is dependent on six enzymes, all of which are localized in the liver. Patients usually present in infancy with severe and often fatal hyperammonemia (16). Most of those who survive have ongoing cerebral insults with repeated episodes of hyperammonemia, despite intense medical intervention (17). Liver transplantation cures the metabolic defect and prevents irreversible neurologic damage if performed early enough $(18,19)$. Auxiliary liver transplantation has been advocated by some as a means of preserving the potential for future gene therapy in the native liver and also to preserve the native liver as a reserve in the event of graft failure $(18,19)$. In our series, two patients were transplanted for citrullinemia. The first child was born with an antenatal diagnosis of citrullinemia by amniocentesis. $\mathrm{He}$ initially did well on dietary therapy (protein restriction). However, he subsequently developed frequent episodes of hyperammonemia with progressive behavioral problems and delays in neurological development. Whole organ liver transplant was done at $11 \mathrm{yr}$ of age. At $5 \mathrm{yr}$ follow-up, he has a functioning graft, persistent behavioral problems and is one grade below expected for age. He no longer has hyperammonemia and protein intake has been increased. The second patient presented with hyperammonemic coma after birth. Despite a severely restricted protein diet, she endured many decompensations and suffered from psychomotor retardation. At $11 \mathrm{yr}$ of age she received a cadaveric left lobe transplant, and had an uncomplicated postoperative course. At $5 \mathrm{yr}$ follow-up, she is doing well but remains in special education classes.

Crigler-Najjar syndrome (CNS) is due to a complete (type I) or incomplete (type II) deficiency of the hepatocyte enzyme bilirubin-UDPglucuronosyltransferase (B-UGT) resulting in unconjugated hyperbilirubinemia (20). CNS type II is distinguished by partial B-UGT activity, which can be induced by phenobarbital to lower bilirubin levels usually at least by $25 \%$ (21). Kernicterus is a serious complication of both CNS types I and II (20). It can precipitate without warning and if full-blown is irreversible. Treatment of CNS type I consists of exchange transfusions soon after birth followed by phototherapy until liver transplantation can be done $(22,23)$. Treatment of CNS type II consists of phenobarbital and the avoidance of drugs that displace bilirubin from its binding to albumin. Children with both types of CNS are usually both physically and mentally entirely healthy, until they suddenly develop kernicterus. For this reason, the decision to transplant an affected child who is jaundiced but otherwise healthy is often postponed, sometimes until it is too late. Auxiliary liver transplantation has been recommended to spare the native liver for possible future gene therapy or hepatocyte transplantation $(24,25)$. Our patient with Crigler-Najjar syndrome type I received an auxiliary left lateral segment graft at 10 months of age prior to the onset of neurologic deficiencies. He is currently within $1 \mathrm{yr}$ of expected grade at school with good liver function and no hyperbilirubinemia.

Methylmalonic acidemia and propionic acidemia are disorders of organic acid metabolism caused by a defect in methylmalonyl-CoA mutase or its cofactor and propionic carboxylase, respectively. Despite intense medical efforts, accumulation of toxic metabolites usually results in death. The few who survive suffer decompensations and numerous complications, particularly severe cerebral insults (26). Patients with methylmalonic acidemia, in addition, may also develop chronic renal failure (26-28). After liver transplantation, the clinical phenotype is corrected and metabolic decompensations usually do not recur $(27,29)$. However, since the metabolic error has only been corrected in liver tissue and the liver is not able to clear all extra-hepatic breakdown products of precursor catabolism, patients usually have persistent excretion of urinary metabolites and mild metabolic acidosis. In our series, three patients were transplanted for disorders of branched-chain amino acid metabolism, two with methylmalonic acidemia and one with propionic acidemia. The latter patient did not survive the perioperative period. The two patients with methylmalonic acidemia presented in the newborn period with lethargy, metabolic acidosis and hyperammonemia. Initially, with conventional therapy, they fared well. One patient, who had methylmalonic acidemia due to mutase $\mathrm{O}$ deficiency, made appropriate developmental and neurological progress, but because 
of early episodes of severe metabolic acidosis, underwent whole liver transplantation at 16 months of age. After 13 months of followup he is well with a good quality of life. The other patient had methylmalonic acidemia due to congenital absence of methylmalonic CoA mutase. She developed many late complications of the disease including anemia, pancreatitis, gastrostomy tube dependence, chorea and developmental delay necessitating special education classes. By the age of $8 \mathrm{yr}$, she was hypertensive with renal failure and had become wheelchair bound. She received a combined heterotopic whole liver and kidney transplant at $13 \mathrm{yr}$ of age. The post-operative course was complicated by hepatic artery thrombosis necessitating another heterotopic whole liver transplant, which was successful. She made a gradual recovery and at $4 \mathrm{yr}$ follow-up, her appetite is improved, she is mildly developmentally delayed and she is ambulatory. This case illustrates the benefit of heterotopic transplantation in the event of graft failure.

Short and long-term survival has been excellent in this current series of patients with metabolic disease, with no operative mortality and 5- and 10-yr survival rates of $78 \%$ and $65 \%$. These results are comparable to the $75 \%$ to $80 \%$ survival rates reported at $5 \mathrm{yr}$ by other centers $(2,30)$. Currently, all of our school-age survivors are able to attend school. The old paradigm of only transplanting patients with end-stage-liver disease has given way to intriguing circumstances in which transplantation serves to prevent or ameliorate other end-organ damage. Among patients whose metabolic disease threatens the central nervous system, quality of life is particularly improved if transplantation is performed prior to the onset of permanent neurological deficits. Living donors may be especially helpful in this subgroup by providing for timely transplantation. Heterotopic or auxiliary liver transplantation should be considered in some patients with hepatic-based enzyme deficiencies and normal structural liver function to spare the native liver for possible future gene therapy and to provide a hepatic reserve in the event of graft failure.

\section{References}

1. Esquivel C, Imatsuki S, Gordon R. Indications for pediatric liver transplantation. J Pediatr 1987: 111: 1039-1045.

2. Busittil R, Seu P, Millis J. Liver transplantation in children. Ann Surg 1991: 213: 48-57.
3. Burdelski M, Rogiers X. Liver transplantation in metabolic disorders. Acta Gastroenterol 1999: 62: 300305.

4. Imatsuki S, Shaw JBW, Starzl T. Liver transplantation for biliary atresia. World J Surg 1984: 8: 5156.

5. Polson R, Rolles K, Calne R, Williams R, Marsden D. Reversal of severe neurologic manifestation of Wilson's disease following orthotopic liver transplantation. Q J Med 1987: 244: 685-691.

6. Lewis J, Bontempo F, Spero J, Ragni M, Starzl T. Liver transplantation in a hemophiliac. NEJM 1985: 312: 1189-1190.

7. Weinberg A, Mize C, Wother H. The occurrence of hepatoma in the chronic form of hereditary tyrosinemia. J Pediatr 1976: 88: 434-438.

8. Mieles L, Esquivel C, Van Thiel D, Konew B. Liver transplantation for tyrosinemia. A review of 10 cases from University of Pittsburgh. Dig Dis Sci 1990: 35: 153-157.

9. Salt A, Baines N, Rolles K, et al. Liver transplantation in tyrosinemia type I. the dilemma of timing the operation. Acta Paediatr 1992: 81: 449-452.

10. Van Spronsen F, Berger R, Smit G, et al. Tyrosinaemia type I. orthotopic liver transplantation as the only definitive answer to a metabolic as well as an oncological problem. J Inherit Metab Dis 1989: 12 (Suppl. 2): 339-342.

11. Silver MM, Beverley DW, Valberg LS, et al. Perinatal hemochromatosis. clinical, morphologic, and quantitative iron studies. Am J Path 1987: 128: 538-554.

12. Cochat P, Deloraine A, Olive F, et al. Primary hyperoxaluria type 1: the therapeutic dilemma. Adv Nephrol Necker Hosp 1995: 24: 227-242.

13. Mizusawa Y, Parnham A, Falk M, et al. Potential for bilateral nephrectomy to reduce oxalate release after combined liver and kidney transplantation for primary hyperoxaluria type I. Clin Trans 1997: 11: 361-363.

14. Cochat P, Gaulier J, Koch Nogueira P, et al. Combined liverkidney transplantation in primary hyperoxaluria type 1. Eur $\mathbf{J}$ Pediatr 1999: 158 (Suppl. 2): S75-S80.

15. BurdelsKi M, UllRich K. Liver transplantation in metabolic disorders: summary of the general discussion. Eur J Pediatr 1999: 158 (Suppl. 2): S95-S96.

16. Msall M, Batshaw M, Suss R. Neurologic outcome in children with inborn errors of urea synthesis. N Engl J Med 1984: 310: $1500-1505$.

17. Fletcher J, Couper R, Moore D, Coxon R, Dorney S. Liver transplantation for citrullinemia improves intellectual function. J Inher Metab Dis 1999: 22: 581-586.

18. Egawa H, Tanaka K, Inomata $\mathrm{Y}$, et al. Auxiliary partial orthotopic liver transplantation from a living related donor: a report of two cases. Transplant Proc 1996: 2: 1071-7072.

19. Uеmoto $S$, Yabe S, Inomata $Y$, et al. Coexistence of a graft with the preserved native liver in auxiliary partial orthotopic liver transplantation from a living donor for ornithine transcarbamylase deficiency. Transplantation 1997: 63: 1026-1028.

20. Crigler J, NajJar V. Congenital familial nonhemolytic jaundice with kernicterus. Pediatrics 1952: 23: 903-913.

21. ArIas I. Chronic unconjugated hyperbilirubinemia without signs of overt hemolysis in adolescents and adults. J Clin Invest 1962: 41: 2233-2245.

22. Karon M, Imach D, Schwarz A. Effective phototherapy in congenital nonobstructive, nonhemolytic jaundice. $\mathrm{N}$ Eng $\mathrm{J}$ Med 1970: 282: 377-381.

23. Mowat A. Liver disorders in children: the indications for liver replacement in parenchymal and metabolic diseases. Transplant Proc 1987: 19: 3236-3241.

24. Asonuma K, Gilbert J, Stein J. Quantitation of transplanted hepatic mass necessary to cure the Gunn rat model of hyperbilirubinemia. J Pediatr Surg 1992: 27: 298-301.

25. Kiuchi T, Edamoto Y, Kaibori M, et al. Auxiliary liver 


\section{Kayler et al.}

transplantation for urea-cycle enzyme deficiency: Lesons from three cases. Transplan Proc 1999: 31: 528-529.

26. LEONARD J. The management and outcome of propionic and methylmalonic acidemia. J Inherit Metab Dis 1995: 18: 430-434.

27. Van't Hoff W, McKiernan P, Surtees R, Leonard J. Liver transplantation for methylmalonic acidaemia. Eur J Pediatr 1999: 158 (Suppl. 2): S70-S74.
28. Matsui S, Mahoney M, Rosenberg L. The natural history of the inherited methylmalonic acidemias. N Engl J Med 1983: 308: 857-856.

29. Saudubray J, Touati G, Delonlay P, et al. Liver transplantation in propionic acidaemia. Eur J Pediatr 1999: 158 (Suppl. 2): S65-S69.

30. OPTN/SRTR. Annual Report. Richmond, Virginia, 2000. 